\title{
Is Symptom-Oriented Follow-Up Still Up to Date?
}

\author{
Christoph Mundhenke ${ }^{a}$ Volker Moebus ${ }^{b}$ \\ aDepartment of Gynecology and Obstetrics, University Hospital Schleswig-Holstein, Campus Kiel, \\ bFrauenklinik, Klinikum Frankfurt-Hoechst, Frankfurt/M., Germany
}

\section{Keywords}

Breast cancer follow-up · Imaging · Laboratory check-up - Lead time - Breast cancer subtypes

\section{Summary}

The main objective of following patients after the primary treatment of breast cancer is the detection of potentially curable events, particularly the detection of local recurrences and contralateral breast cancer. Additionally, medical counseling on therapies, psychosocial aspects, side effects of therapies, and lifestyle interventions is important to improve the quality of life. There is an ongoing discussion about whether early detection of asymptomatic metastasis could improve the course of disease. Today, the follow-up is still symptom-orientated. Intensified imaging and laboratory check-ups have not been beneficial for the patients' survival. A follow-up in the first 2-3 years is recommended every 3 months. Because of the decreasing incidence of recurrence from year 4, 6-monthly screening intervals are recommended. The screening should include a history, physical examination, and a consultation. Routine diagnostic imaging - except for mammography/ultrasound - is not indicated in asymptomatic patients. Innovative therapies for patients with metastatic breast cancer have been introduced. Therefore, measures of an intensified follow-up could change in the future as novel endocrine combination or targeted therapies in molecular subtypes could significantly improve the survival in early detected metastasis. In the future, more individualized follow-up programs are conceivable. However, this idea is so far not supported by the available data.
Schlüsselwörter

Brustkrebsnachsorge · Bildgebung ·

Laboruntersuchungen - Lead time - Brustkrebssubtypen

\section{Zusammenfassung}

Das wichtigste Ziel der Nachsorge nach einem primären Mammakarzinom ist die Erkennung eines potenziell heilbaren Ereignisses, wie ein Lokalrezidiv oder ein kontralaterales Mammakarzinom. Zusätzlich ist die Beratung in Bezug auf die laufende Therapie, zu psychosozialen Belangen, therapiebedingten Nebenwirkungen und zu einer Lebensstil-Intervention wichtig, um die Lebensqualität und die Wirkungsweise der Therapien zu verbessern. Es gibt eine anhaltende Diskussion darüber, ob eine frühzeitige Entdeckung nicht symptomatischer Metastasen den Krankheitsverlauf günstig beeinflussen könnte. Heute ist die Nachsorge rein symptomorientiert. Eine intensivierte Bildgebung und Laboruntersuchungen haben keinen Vorteil im Hinblick auf ein verbessertes Überleben. Eine Nachsorge in den ersten 2-3 Jahren nach Ersterkrankung wird alle 3 Monate empfohlen. Da danach die Rezidivhäufigkeit sinkt, wird ab dem 4. Jahr nach Erkrankung ein halbjährliches Intervall empfohlen. Die Nachsorge sollte neben der Anamnese eine körperliche Untersuchung und eine Beratung einschließen. Eine weitere Routinediagnostik - außer Mammographie und Ultraschall - ist bei nicht symptomatischen Patientinnen nicht indiziert. In den vergangenen Jahren sind innovative und effektive Therapieoptionen für das metastasierte Mammakarzinom eingeführt worden. Von daher wäre es denkbar, dass ein sehr früher Einsatz dieser Therapien zumindest bei einigen molekularen Subtypen zu einem verbesserten Überleben führen könnte. Zukünftig sind daher durchaus stärker individualisierte Nachsorgeprogramme denkbar. Bislang gibt es für diese Überlegungen jedoch keine bestätigende Datenlage.

\section{KARGER \\ Fax +497614520714 \\ Information@Karger.com}

www.karger.com (c) 2013 S. Karger GmbH, Freiburg

$1661-3791 / 13 / 0085-0336 \$ 38.00 / 0$

Accessible online at:

www.karger.com/brc
Prof. Dr. med. Christoph Mundhenke

Klinik für Gynäkologie und Geburtshilfe

Universitätsklinikum Schleswig-Holstein, Campus Kiel

Arnold-Heller Strasse 3, 24105 Kiel, Germany

cmundhenke@hotmail.com 


\section{Introduction}

Modern follow-up after primary breast cancer is characterized by a minimum of imaging procedures such as mammography and breast ultrasound. Additionally, medical counseling on therapies, side effects of therapies, and lifestyle interventions is important to improve the quality of life.

The main objective of following patients after the primary treatment of breast cancer is the detection of potentially curable events, particularly the detection of local recurrences and contralateral breast cancer (CBC). With increasing complexity and time length of primary adjuvant treatment, the surveillance and counseling during the follow-up period becomes increasingly important. Counseling during follow-up visits should preserve or, in case of therapy-related morbidity, improve the quality of life. In recent years, innovative and effective endocrine and targeted therapies for patients with metastatic breast cancer have been introduced. Some were able to influence the course of disease and to improve the diseasefree survival (DFS) and overall survival (OS). Therefore, an early detection of asymptomatic metastasis could be beneficial in specific molecular subtypes.

\section{Contents of Follow-Up}

The follow-up should still be symptom-orientated. Intensified imaging and laboratory check-ups have not been beneficial for the patients' survival [1-4]. Intensified steps are able to earlier detect metastasis in asymptomatic patients. But this correlates with a reduced progression-free survival (PFS) and a reduced quality of life, as the number of toxic therapies is increased and therapies start early [4].

So far, the follow-up intervals are recommended as every 3 months during the first 3 years after breast cancer diagnosis and twice yearly in years 4 and 5, and yearly from year 6. Patients are motivated to perform a monthly self-examination and to report changes in well-being or newly occurring symptoms.

Beside the detection of ipsilateral or locoregional recurrence, the follow-up mainly aims to support psychosocial aspects and to offer counseling for long-term treatment and side effects of breast cancer-related treatment. Psychosocial support and counseling of patients must be available in each breast cancer unit [5].

Non-compliance to long-term endocrine therapy is significantly correlated with reduced OS [6]. During follow-up visits, therapy side effects should be recognized and approached to improve compliance.

Often the role of breast magnetic resonance imaging (MRI) in follow-up is discussed. So far, clinical examination and mammography are equally sensitive compared to MRI in detecting recurrent disease, but MRI shows a higher specificity. Use of MRI can be recommended in cases when clinically, or after imaging with ultrasound and mammography, the suspicion of disease recurrence persists [7].

Several studies on intensified early detection and a Cochrane meta-analysis have been published [4]. 2 large prospective randomized Italian studies still serve as the main reference for the creation of international guidelines on breast cancer follow-up $[1,2]$. Both compared a patient group with a standard follow-up to a group with enhanced laboratory and imaging measures (including repeated liver sonography, bone scintigraphy, and chest X-rays). No difference in OS was observed after 5 years in both trials. Therefore chest X-rays, liver sonography, and laboratory work-ups cannot be recommended routinely after primary breast cancer.

Routine follow-up examinations in asymptomatic patients should comprise history (for specific symptoms), physical examination, mammography, sonography of the breast, MRI of the breast in case of inconclusive conventional imaging, and a gynecologic pelvic examination during tamoxifen therapy. The clinical examination should include breasts, regional lymph nodes, and the thoracic wall [8].

In a large meta-analysis of all Medline and Cochrane Collaboration Library publications since 1999, tumor markers as carcinoma antigen (CA) 15-3 and CA 27.29 were shown to increase 5-6 months before symptoms of a metastasis occur. But, until today, there are no randomized studies showing an improved DFS or OS, or an improved quality of life, by regular tumor marker analysis [9].

A growing issue is the use of positron emission tomography (PET) scans in the follow-up. For this purpose, a meta-analysis of 43 studies exists (15 prospectively, 16 retrospectively, others not defined) [10]. PET was more effective than computed tomography (CT) and MRI, showing mediastinal metastases and mediastinal lymph node metastases more accurately than bone scintigraphy in the presentation of bone metastases. However, the authors emphasized that all studies were performed only for suspected metastasis or disease recurrence.

Evidence of persisting isolated tumor cells in the bone marrow is associated with an increased risk of recurrence. However, so far, it has remained uncertain as to how far the adjuvant therapy should be adjusted in this regard so that there is a benefit for the patient [11]. Until now, tumor cell detection is explicitly not recommended in the routine follow-up.

\section{Locoregional Recurrence}

Locoregional recurrences include chest wall recurrences, in-breast recurrences, and others (tumor spread in the internal mammary, supraclavicular, infraclavicular, ipsilateral axillary nodes or in the non-breast skin of the ipsilateral chest wall). All other sites of tumor recurrence are classified as distant metastases. The early detection of locoregional 
recurrences represents a potentially curable situation. Mammography-detected primaries are more likely to be noninvasive, of low tumor stage, and node-negative. Mammography, ultrasound, and clinical examination can be recommended for early detection of locoregional recurrence.

\section{Contralateral Breast Cancer}

Breast cancer patients have a 2.5-5-fold risk for CBC [1214]. Young patients with breast cancer treated with tangential breast irradiation experience an increased risk of $\mathrm{CBC}$. Adjuvant chemotherapy seems to reduce the risk of $\mathrm{CBC}$ only during the first 5 years after treatment. $\mathrm{CBC}$ is diagnosed with more favorable prognostic factors when physical examination and mammography are used during follow-up of the breast cancer. Mammography-detected primaries are more likely to be noninvasive, of low tumor stage, and node-negative. Annual mammography, routine physical examination, and patient self-examination are recommended as surveillance to detect ipsilateral breast tumor recurrence (IBTR) while it can be cured by salvage surgery. MRI should be used to distinguish a recurrent tumor from benign post-therapeutic changes in the treated breast [15-18].

\section{Secondary Malignancies}

There is a significantly increased risk of second malignancies in women treated for breast cancer. These may be due to a coincidence (ovary), similar mechanisms in carcinogenesis (endometrium), treatment side effects (endometrium), or genetic or unknown associations (colon). Patients with breast cancer should be screened for secondary malignancies according to the current guidelines. The impact of imaging diagnostics is questionable, even in high-risk patients. Routine transvaginal sonography or hysteroscopy with biopsy increases the number of interventions in benign changes without proven effects of early detection of malignant disease [19-23].

\section{Follow-Up in the First 6 Months}

In the early phase of the follow-up there is a focus on treatment-related side effects. These are declining [24-26] due to improved surgical and radiation techniques. Patients on endocrine treatment frequently complain about effects of hormone deprivation (osteoporosis, musculoskeletal complaints, climacteric syndrome) [27-30]. With regard to treatment compliance, these women need detailed information and treatment of side effects. Depending on age and individual life planning, counseling on contraception, family planning, and potential pregnancies after breast cancer must be performed [31, 32]. The impact of newly diagnosed disease on family, work, and social life must be clarified. There remains a constant fear of recurrence, which needs to be addressed.

\section{Follow-Up and Lifestyle}

Moderate physical activity and weight reduction in obese women during follow-up is able to improve the quality of life and physical performance, reduce fatigue, and optimize outcome [33-38]. Therefore, patients should be encouraged to take and be supported in measures to achieve these goals. In major epidemiological studies, $>25 \%$ of postmenopausal breast cancer patients were found to have undiagnosed diabetes mellitus (DM) (type II). Early treatment of DM could improve breast cancer diagnosis [39].

A healthy, low-fat diet and physical activity can improve the DFS and OS and can improve the physical and mental well-being [40-42]. There is increasing data for the poor influence of obesity $\left(\mathrm{BMI} \geq 30 \mathrm{~kg} / \mathrm{m}^{2}\right)$ on DFS and cancer-specific mortality [43, 44]. The preservation of physical activity and body weight in the normal range leads to a significant improvement in quality of life, reduced fatigue, and better physical functions [45].

Continued smoking after breast cancer is correlated with a 4-fold increase in non-breast cancer-related mortality and a 2 -fold increase in breast cancer-related mortality. Smoking cessation reduces breast cancer-related and non-related mortality [46] (fig. 1).

Thus, issues such as physical activity, weight reduction, and restriction of nicotine and alcohol intake as part of the followup should be addressed, and type II diabetes should be excluded or adequately managed after diagnosis of breast cancer in postmenopausal women.

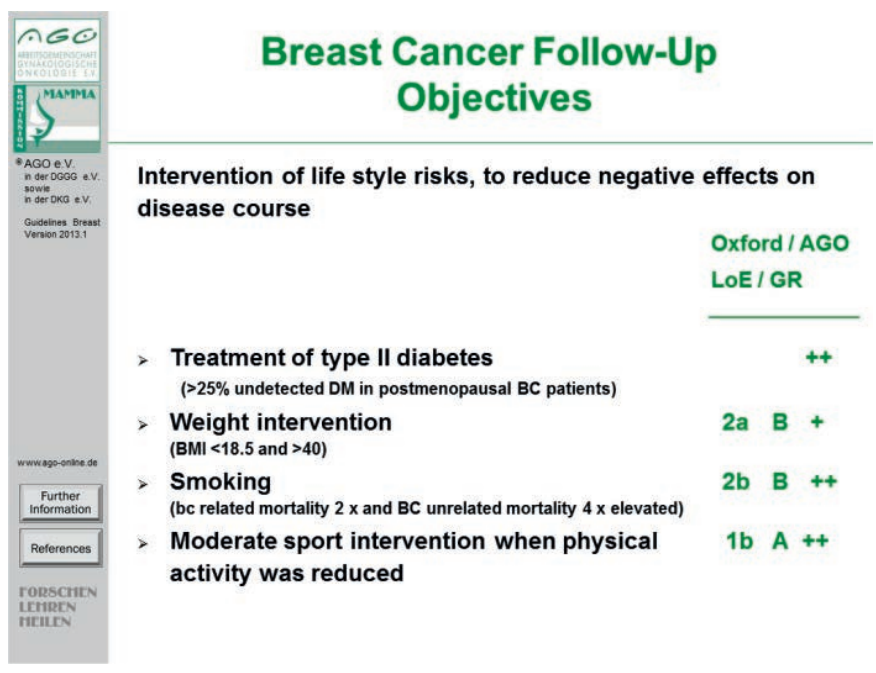

Fig. 1. AGO (Arbeitsgemeinschaft Gynäkologische Onkologie recommendation on breast cancer follow-up: Intervention on lifestyle risks (AGO/Breast 2013). 
Fig. 2. Follow-up care for breast cancer (including LCIS/DCIS): Recommendations for asymptomatic patients (modified ASCO guidelines 2012, NCCN 2, 2011, and S3 national German guideline 2012).

*Continued follow-up visits if still on adjuvant treatment. **First mammography 6-12 months after completion of BCT.

LCIS = Lobular carcinoma in situ, DCIS = ductal carcinoma in situ, ASCO $=$ American Society of Clinical Oncology, NCCN = National Comprehensive Cancer Network, $\mathrm{BCT}=$ breast conserving therapy.

\begin{tabular}{|c|c|c|c|c|}
\hline \multirow{2}{*}{\multicolumn{2}{|c|}{$\begin{array}{l}\text { Clinical follow-up } \\
\text { Years after primary therapy }\end{array}$}} & \multicolumn{2}{|c|}{ Follow-Up* } & \multirow{2}{*}{$\begin{array}{c}\text { Screening } \\
>6\end{array}$} \\
\hline & & 1 & 5 & \\
\hline \multirow{2}{*}{\multicolumn{2}{|c|}{$\begin{array}{l}\text { History, physical } \\
\text { examination, counseling }\end{array}$}} & $\begin{array}{l}\text { inv.: } \\
\text { every } 3 \text { months }\end{array}$ & $\begin{array}{c}\text { inv.: } \\
\text { every } 6 \text { months }\end{array}$ & $\begin{array}{l}\text { inv.: } \\
\text { every } 12 \text { months }\end{array}$ \\
\hline & & \multicolumn{2}{|c|}{ LCIS / DCIS: every 6-12 months } & $\begin{array}{l}\text { LCIS/DCIS: } \\
\text { every } 12 \text { months }\end{array}$ \\
\hline \multicolumn{2}{|c|}{ Self-examination } & \multicolumn{3}{|c|}{ monthly } \\
\hline \multicolumn{2}{|c|}{$\begin{array}{l}\text { Imaging modalities and } \\
\text { biochemistry }\end{array}$} & \multicolumn{3}{|c|}{$\begin{array}{l}\text { indicated only by complaints, clinical findings or } \\
\text { suspicion of recurrence }\end{array}$} \\
\hline \multirow{3}{*}{$\begin{array}{l}\text { Mammo- } \\
\text { graphy } \\
\text { and sono- } \\
\text { graphy }\end{array}$} & inv.: $B C T^{* *}$ & $\begin{array}{l}\text { ipsilat.: every 6-12 } \\
\text { months } \\
\text { contralat.: every } \\
12 \text { months }\end{array}$ & on both sides: & very 12 months \\
\hline & $\begin{array}{l}\text { inv.: } \\
\text { Mastectomy }\end{array}$ & \multicolumn{3}{|c|}{ contralateral every 12 months } \\
\hline & LCIS / DCIS & \multicolumn{3}{|c|}{ every 12 months } \\
\hline
\end{tabular}

\section{Long-Term Follow-Up}

There is no clear evidence to recommend a 3-monthly follow-up. Some guidelines recommended 3-6 monthly intervals. It has been shown that after 2 years following the diagnosis of breast cancer there is no evidence to support the view that a regular clinical review improves the psychological morbidity or quality of life. Follow-up of women with ductal carcinoma in situ (DCIS) includes interval history and physical examinations every 6-12 months for 5 years and then annually as well as yearly diagnostic mammography. In patients undergoing breast-conserving therapy, the first follow-up mammogram should be performed 6-12 months after completion of the breast-conserving radiation therapy.

\section{Follow-Up Guidelines}

A follow-up in the first 2-3 years is recommended every 3 months [45-48]. Because of the decreasing incidence of recurrence from year 4, 6-monthly screening intervals are recommended. From year 6 onwards, patients can be transferred back to the normal cancer screening program. The screening should include a history, physical examination, and a consultation. Routine diagnostic imaging - except mammography/ultrasound - is not indicated in asymptomatic patients. Tumor marker controls are not indicated in asymptomatic patients. Further diagnostic procedures should be performed only in patients with clinically suspected cancer or symptoms of recurrence (fig. 2).

Integral part of the follow-up is the early detection of curable local recurrence, $\mathrm{CBC}$ and other curable second primary tumors, and the detection and treatment of therapy-related complications, avoiding unnecessary investigations. Depending on age and life situation, every patient must be fully advised. As long as there is no treatment option with a claim to cure, early detection of asymptomatic metastatic disease is useless.

\section{Conclusions}

Based on current evidence, the Arbeitsgemeinschaft Gynäkologische Onkologie (AGO) and other organizations that publish guidelines discourage additional follow-up examinations in asymptomatic patients, but encourage the performance of future studies on the relevance of additional tests in the context of modern imaging and treatment modalities.

Intensified surveillance has proven to decrease the lead time until the detection of distant metastases in comparison to conventional surveillance, but has not been shown to improve OS.

Innovative therapies for patients with metastatic breast cancer have been introduced. Therefore, measures of an intensified follow-up could change in the future as novel endocrine combination or targeted therapies in molecular subtypes could significantly improve survival in early detected metastasis. In the future, more individualized follow-up programs are conceivable. So far, however, this idea is not supported by the available data. This objective should therefore be evaluated in prospective clinical trials.

\section{Acknowledgments}

This review is based on the 2013 updated treatment recommendations of the German AGO/Breast. We thank all members of the AGO/Breast commission for their valuable contributions. We especially thank our colleagues I. Bauerfeind, J. Bischoff, J. Blohmer, M. Böhme, S. Costa, I. Diel, B. Gerber, V. Hanf, G. Heinrich, W. Janni, M. Kaufmann, M. Lux, C. Oberhoff, A. Scharl, and C. Thomssen who updated the recommendations on breast cancer follow-up in the recent years.

\section{Disclosure Statement}

The authors declare that they have no competing interests. 


\section{References}

1 The GIVIO Investigators: Impact of follow-up testing on survival and health-related quality of life in breast cancer patients. A multicenter randomized controlled trial. JAMA 1994;271:1587-1592.

$\checkmark 2$ Rosselli del Turco M, Palli D, Cariddi A, et al.: Intensive diagnostic follow-up after treatment of primary breast cancer. A randomized trial. National Research Council Project on Breast Cancer Follow-Up. JAMA 1994;271:1593-1597.

3 Palli D, Russo A, Saieva C, et al.: Intensive vs clinical follow-up after treatment of primary breast cancer: 10-year update of a randomized trial. National Research Council Project on Breast Cancer Follow-Up. JAMA 1999;281:1586.

4 Rojas MP, Telaro E, Moschetti I, et al.: Follow-up strategies for women treated for early breast cancer. Cochrane Database Syst Rev 2005;25: CD001768.

$\checkmark 5$ Fors EA, Bertheussen GF, Thune I, et al.: Psychosocial interventions as part of breast cancer rehabilitation programs? Results from a systematic review. Psychooncology 2011;20:909-918.

6 Hershman DL, Shao T, Kushi LH, et al.: Early discontinuation and non-adherence to adjuvant hormonal therapy are associated with increased mortality in women with breast cancer. Breast Cancer Res Treat 2011;126:529-537.

7 Drew PJ, Kerin MJ, Turnbull LW, et al.: Routine screening for local recurrence following breastconserving therapy for cancer with dynamic contrast-enhanced magnetic resonance imaging of the breast. Ann Surg Oncol 1998;5:265-270.

$\checkmark 8$ Grunfeld E, Dhesy-Thind S, Levine M: Clinical practice guidelines for the care and treatment of breast cancer: follow-up after treatment for breast cancer (summary of the 2005 update). CMAJ 2005;172:1319-1320.

$\checkmark$ Harris L, Fritsche H, Mennel R, et al.: American Society of Clinical Oncology 2007 update of recommendations for the use of tumor markers in breast cancer. J Clin Oncol 2007;25:5287-5312.

10 Pan L, Han Y, Sun X, et al.: FDG-PET and other imaging modalities for the evaluation of breast cancer recurrence and metastases: a meta-analysis. J Cancer Res Clin Oncol 2010;136:1007-1022.

11 Janni W, Rack B, Schindlbeck C, et al.: The persistence of isolated tumor cells in bone marrow from patients with breast carcinoma predicts an increased risk for recurrence. Cancer 2005;103:884891.

12 Yerushalmi R, Kennecke H, Woods R, et al.: Does multicentric/multifocal breast cancer differ from unifocal breast cancer? An analysis of survival and contralateral breast cancer incidence. Breast Cancer Res Treat 2009;117:365-370.

13 Hooning MJ, Aleman BM, Hauptmann M, et al.: Roles of radiotherapy and chemotherapy in the development of contralateral breast cancer. J Clin Oncol 2008;26:5561-5568.

14 Bertelsen L, Mellemkjaer L, Christensen J, et al.: Age-specific incidence of breast cancer in breast cancer survivors and their first-degree relatives. Epidemiology 2009;20:175-180.

15 Montgomery DA, Krupa K, Cooke TG: Follow-up in breast cancer: does routine clinical examination improve outcome? A systematic review of the literature. Br J Cancer 2007;97:1632-1641.

16 Beinart G, Gonzalez-Angulo AM, Broglio K, et al.: Clinical course of 771 patients with bilateral breast cancer: characteristics associated with overall and recurrence-free survival. Clin Breast Cancer 2007; 7:867-874.

17 Samant RS, Olivotto IA, Jackson JS, et al.: Diagnosis of metachronous contralateral breast cancer. Breast J 2001;7:405-410.

18 Kollias J, Ellis IO, Elston CW, et al.: Prognostic significance of synchronous and metachronous bilateral breast cancer. World J Surg 2001;25:11171124.

19 Andersson M, Jensen MB, Engholm G, et al.: Risk of second primary cancer among patients with early operable breast cancer registered or randomised in Danish Breast Cancer cooperative Group (DBCG) protocols of the 77, 82 and 89 programmes during 1977-2001. Acta Oncol 2008;47: $755-764$.

20 Schaapveld M, Visser O, Louwman MJ, et al.: Risk of new primary nonbreast cancers after breast cancer treatment: a Dutch population-based study. J Clin Oncol 2008;26:1239-1246.

21 Chan JK, Manuel MR, Cheung MK, et al.: Breast cancer followed by corpus cancer: is there a higher risk for aggressive histologic subtypes? Gynecol Oncol 2006;102:508-512.

22 Kirova YM, De Rycke Y, Gambotti L, et al.: Second malignancies after breast cancer: the impact of different treatment modalities. Br J Cancer 2008;98:870-874.

23 Brown LM, Chen BE, Pfeiffer RM, et al.: Risk of second non-hematological malignancies among 376,825 breast cancer survivors. Breast Cancer Res Treat 2007;106:439-451.

24 Nielsen I, Gordon S, Selby A: Breast cancer-related lymphedema risk reduction advice: a challenge for health professionals. Cancer Treat Rev 2008; 34:621-628.

25 Kaufmann M, Jatoi I, Petit JI (eds): Atlas der Brustchirurgie. Heidelberg, Springer, 2008.

26 Bonneterre J, Roche H, Kerbrat P, et al.: Longterm cardiac follow-up in relapse-free patients after six courses of fluorouracil, epirubicin, and cyclophosphamide, with either 50 or $100 \mathrm{mg}$ of epirubicin, as adjuvant therapy for node-positive breast cancer: French adjuvant study group. J Clin Oncol 2004;22:3070-3079.

27 The Steering Committee on Clinical Practice Guidelines for the Care and Treatment of Breast Cancer: Follow-up after treatment for breast cancer. CMAJ 1998;158(suppl 3):S65-S70.

28 Grunfeld E, Dhesy-Thind S, Levine M: Clinical practice guidelines for the care and treatment of breast cancer: follow-up after treatment for breast cancer (summary of the 2005 update). CMAJ 2005;172:1319-1320.

29 Fan HG, Houede-Tchen N, Yi QL, et al.: Fatigue, menopausal symptoms, and cognitive function in women after adjuvant chemotherapy for breast cancer: 1- and 2-year follow-up of a prospective controlled study. J Clin Oncol 2005;23:8025-8032.

30 Hickey M, Saunders C, Partridge A, et al.: Practical clinical guidelines for assessing and managing menopausal symptoms after breast cancer. Ann Oncol 2008;19:1669-1680.

31 Schover LR: Premature ovarian failure and its consequences: vasomotor symptoms, sexuality, and fertility. J Clin Oncol 2008;26:753-758.

32 Gerber B, Dieterich M, Muller H: Controversies in preservation of ovary function and fertility in patients with breast cancer. Breast Cancer Res Treat 2008;108:1-7.

33 Beasley JM, Kwan ML, Chen WY, et al.: Meeting the physical activity guidelines and survival after breast cancer: findings from the After Breast Cancer Pooling Project. Breast Cancer Res Treat 2012;131:637-643.

34 Ewertz M, Jensen MB, Gunnarsdóttir KÁ, Højris I, Jakobsen EH, Nielsen D, Stenbygaard LE, Tange UB, Cold S: Effect of obesity on prognosis after early-stage breast cancer. J Clin Oncol 2011; 29:25-31.

35 Voskuil DW, van Nes JG, Junggeburt JM, et al.: Maintenance of physical activity and body weight in relation to subsequent quality of life in postmenopausal breast cancer patients. Ann Oncol 2010;21:2094-2101.

36 National Comprehensive Cancer Network: NCCNGuidelines version 1, 2011. Cancer-related fatigue. www.nccn.org.

37 Bicego D, Brown K: Effects of exercise on quality of life in women living with breast cancer: a systematic review. Breast J 2009;15:45-51.

38 Cramp F, Daniel J: Exercise for the management of cancer-related fatigue in adults. Cochrane Database Syst Rev 2008;2:CD006145.

39 Griffiths RI, Danese MD, Gleeson ML, Valderas JM: Epidemiology and outcomes of previously undiagnosed diabetes in older women with breast cancer: an observational cohort study based on SEER-Medicare. BMC Cancer 2012;12:613.

40 Chlebowski RT, Blackburn GL, Thomson CA, et al.: Dietary fat reduction and breast cancer outcome: interim efficacy results from the Women's Intervention Nutrition Study. J Natl Cancer Inst 2006;98:1767-1776.

41 Demark-Wahnefried W, Case LD, Blackwell K, et al.: Results of a diet/exercise feasibility trial to prevent adverse body composition change in breast cancer patients on adjuvant chemotherapy. Clin Breast Cancer 2008;8:70-79.

42 McNeely ML, Campbell KL, Rowe BH, et al.: Effects of exercise on breast cancer patients and survivors: a systematic review and meta-analysis. CMAJ 2006;175:34-41

43 Calle EE, Rodriguez C, Walker-Thurmond K, et al.: Overweight, obesity, and mortality from cancer in a prospectively studied cohort of U.S. adults. N Engl J Med 2003;348:1625-1638.

44 Ewertz M, Jensen MB, Gunnarsdóttir KA, et al.: Effect of obesity on prognosis after early-stage breast cancer. J Clin Oncol 2011;29:25-31.

45 Voskuil DW, van Nes JG, Junggeburt JM, et al.: Maintenance of physical activity and body weight in relation to subsequent quality of life in postmenopausal breast cancer patients. Ann Oncol 2010; 21:2094-2101.

46 Braithwaite D, Izano M, Moore DH, et al.: Smoking and survival after breast cancer diagnosis: a prospective observational study and systematic review. Breast Cancer Res Treat 2012;136:521-533.

47 Khatcheressian JL, Smith TJ: Randomized trial of long-term follow-up for early-stage breast cancer: a comparison of family physician versus specialist care. J Clin Oncol 2006;24:835-837.

48 National Comprehensive Cancer Network: NCCN Guidelines version 2, 2011. Breast cancer. Clinical Practice Guidelines in Oncology ${ }^{\mathrm{TM}}$. www.nccn.org. 